\title{
Histopathology and molecular identification of Henneguya pseudoplatystoma
}

\author{
Romário Oliveira de Sales ${ }^{1}$, Juliana Rosa Carrijo Mauad ${ }^{1}$, Claucia Aparecida Honorato ${ }^{1}$ \\ Kesia Esther da Silva ${ }^{1}$, Jaqueline Verconti ${ }^{1}$, Peceu Magyve Ragagnin ${ }^{1}$, Sibele Borsuk ${ }^{2}$ \\ Mauricio Laterça Martins ${ }^{3}$ \& Simone Simionatto ${ }^{1}$ \\ ${ }^{1}$ Universidade Federal da Grande Dourados (UFGD), Dourados, Mato Grasso do Sul, Brazil \\ ${ }^{2}$ Universidade Federal de Pelotas (UFPEL), Pelotas, Rio Grande do Sul, Brazil \\ ${ }^{3}$ Universidade Federal de Santa Catarina (UFSC), Florianópolis, SC, Brazil \\ Corresponding author: Claucia Aparecida Honorato (clauciaahonorato@gmail.com)
}

\begin{abstract}
The present study proposes to characterize the parasites isolated during the initial phase of production in fish farms located in Mato Grosso do Sul in the central-western region of Brazil, using histopathology analysis and molecular techniques. A total of 340 hybrid surubim fish (Pseudoplatystoma reticulatum $\times P$. corruscans) from four farms were examined during the co-feeding phase. Histopathology analysis showed that $10.9 \%(\mathrm{n}=37)$ of the fish were infected with parasites. Branchitis, lifting epithelium, hypertrophy of epithelial cells, lamellar fusion, aneurisms and infection in the bone tissue of the gill filament was observed. The parasite species was determined by amplification of the 18S rRNA gene followed by sequencing. The phylogenetic analysis of nucleotide sequences indicates a close relationship (99.6\%) with Henneguya pseudoplatystoma reported to be infecting the hybrid Pseudoplatystoma. This study demonstrates the occurrence of $H$. pseudoplatystoma in hybrid surubim ( $P$. reticulatum $\times P$. corruscans) during the co-feeding phase in fish farms in Mato Grosso do Sul. Also, molecular techniques provide a faster and sensitive method to identify fish parasites, and may assist in the development of new management techniques aimed at improving the sanitary conditions contributing to the reduction of mortality rates in these animals.
\end{abstract}

Keywords: Henneguya pseudoplatystoma; parasite; fish farm; co-feeding; histopathology; aquaculture

\section{INTRODUCTION}

Fish farming in Brazil is going through a consolidation and expansion phase, in terms of the production of animal protein. The intensification of farming requires greater knowledge about the proper management needed to improve the health conditions of the fish, especially in the early stages of production (TavaresDias \& Oliveira, 2017). Currently, hybrid surubim catfish (Pseudoplatystoma reticulatum female $\times P$. corruscans male) appears as one of the main species in the production system. The low cost, combined with the rapid growth, facilitates the intensive production of this species, presenting great potential for industrial exploration and high economic returns (Jerônimo et al., 2016).

\footnotetext{
Corresponding editor: Jesús Ponce-Palafox
}

The success of aquaculture depends on several health aspects, such as prophylaxis, diagnosis and therapeutics. However, sanitation practices are rarely adopted by fish farmers owing to the growing demands from the domestic and external markets, and this negatively affects fish production. At the co-feeding stage, fishes are sensitive to stress and abrupt changes in water quality (Honorato et al., 2015), which makes them susceptible to parasitic agents. These pathogens are considered the leading causes of high rates of fish mortality, resulting in massive economic losses (Naldoni et al., 2009; Tavares-Dias \& Oliveira, 2017). In Brazil there are 10,094 of surubim-producing properties, most of them are located in the centralwestern region of the country (IBGE, 2017), and production in these states is about 4,766 $\mathrm{t}$ in 2017 (Peixe BR, 2019). 
Parasites of the genus Henneguya are considered one of the most abundant parasites affecting larval fish stages, either in the wild or under farmed conditions (Naldoni et al., 2011; Vidal \& Luque, 2017), with more than 200 described species (Dyková \& Lom, 1992; Lom \& Dyková, 2006). In Brazil, 40 species of Henneguya sp. (Cnidaria: Myxosporea: Myxobolidae) were described infecting a large variety of commercial fishes (Eiras et al., 2008; Naldoni et al., 2011; Vidal \& Luque, 2017). Infection due to Henneguya species occurs mainly in the gill arches, which leads to destruction of the gill filaments, causing respiratory failure (Dyková \& Lom, 1992; Velasco et al., 2015), but it can also be observed to be parasitizing kidney of freshwater fish Piaractus mesopotamicus, causing several histological alterations (Manrique et al., 2017).

The identification of parasites present in fish farming tanks contributes to the development of new management techniques aimed at the improvement of sanitary indicators. Although fish production is concentrated in the central-western region of Brazil, there are few studies of parasite identification under present farming conditions. The objective of this study was to characterize parasites recovered from hybrid surubim during the co-feeding phase, using molecular techniques, and describe histopathological aspects of infection in four fish farms located in Mato Grosso do Sul, central-western Brazil.

\section{MATERIALS AND METHODS}

\section{Samples collection}

The specimens of surubim were acquired from four fish farms located in Mato Grosso do Sul, central-western Brazil (2026'32'S, 54 51'37'W), from April 2011 to February 2012. Fish were cultured in intensive system tanks of $1,000 \mathrm{~L}$ capacity, with constant water flow, and a co-feeding regime of $2-3 \%$ of the biomass. Cofeeding is supplied of saline brine shrimp with the wet diet determined as a food transition phase, that has a gradual replacement of living food to the inert one (Jomori et al., 2012). In this co-feeding phase, there is the concomitant supply of two types of food divided into nine meals per day.

Tanks were cleaned weekly, and 3 to $5 \mathrm{mg} \mathrm{L}^{-1} \mathrm{NaCl}$ was used for prophylactic handling, which is a routine management practice adopted in the fish producing facilities. The fish had a weight of $14.8 \mathrm{~g}$ and a mean total length of $13.7 \mathrm{~cm}$, after the feeding phase of the live feed for the diets.

\section{Histopathology and parasitological analysis}

Classification by size was performed every 15 days. Fish were anesthetized with clove oil $\left(50 \mathrm{mg} \mathrm{L}^{-1}\right)$ for macroscopic observation and evaluation of clinical signs. After euthanizing, medullar section scrapings of the body surface were made for observation. The euthanasia method was approved by the Ethics Committee on Animal Use of Federal University of Grande Dourados (CEUA N010/2012). The gill arches were removed, and fragments observed under a microscope. For histopathology, gill fragments were fixed in $10 \%$ buffered formalin solution $(0.1 \mathrm{M}, \mathrm{pH} 7.3)$ for $24 \mathrm{~h}$ followed by washing in $70 \%$ alcohol. After fixing, the samples were dehydrated, cleared, included in paraffin with plastic polymer Histosec $\left(\right.$ Merck $\left.^{\circledR}\right)$ for cross-sections of 2-5 $\mu \mathrm{m}$, and stained with Hematoxylin-Eosin. Photomicrographs were obtained using an Olympus BX41 microscope. Parasites were processed (Eiras et al., 2006) and identified (Lom, 1981; Eiras et al., 2006; Thatcher, 2006). The parasite's prevalence was calculated, according to Bush et al. (1997).

\section{DNA extraction}

Parasites were recovered from gill arches that macroscopically showed lesions and were subjected to genomic DNA extraction using DNeasy Blood \& Tissue Kit (Qiagen, Crawley, United Kingdom), according to the manufacturer's instructions. The concentration of the total DNA was determined by evaluating the optical density measured using a spectrophotometer (BioDrop, Walnut Creek, CA, USA).

\section{Primer designs and DNA amplification}

Polymerase Chain Reaction (PCR) of two overlapping fragments was performed using specific primers: $18 \mathrm{~S}$ rRNA forward 5' TGCCAAGGTTTTTACGGGT 3' and 18S rRNA reverse 5' CCGCAGGCTCCACCC 3'. Primers were designed through the information stored in GenBank (accession \# EF191200) for the ribosomal RNA (rRNA) 18S gene of Henneguya sp. The sequences were submitted for global alignment with Clustal X in the Vector NTI ${ }^{\circledR} 11.0$ (Invitrogen) program to identify the preserved regions of the species. Specific primers were designed for the rRNA, based on the conserved regions identified in the alignment. The PCR reaction was performed in $50 \mu \mathrm{L}$ consisting of $10-50 \mathrm{ng}$ of DNA template; $25 \mu \mathrm{L}$ of GoTaq ${ }^{\circledR}$ Green Master Mix, 2X,(Promega, Madison, WI, USA); $15 \mu \mathrm{L}$ of NucleaseFree Water (Promega, Madison, WI, USA); and $50 \mathrm{pM}$ of each primer. The reaction was conducted in a thermocycler (Mastercycler Gradient, Eppendorf) with the following conditions: an initial denaturation step at $95^{\circ} \mathrm{C}$ for $5 \mathrm{~min}$, followed by 35 cycles of denaturation $94^{\circ} \mathrm{C}$ for $1 \mathrm{~min}, 52^{\circ} \mathrm{C}$ for $1 \mathrm{~min}$ and $72^{\circ} \mathrm{C}$ for $1 \mathrm{~min}$, with a final extension at $72^{\circ}$ for $10 \mathrm{~min}$. The PCR 
products were electrophoresed in $1.0 \%$ agarose gels in Tris-acetate-EDTA buffer gel and stained with GelRed (Uniscience).

\section{DNA sequencing}

PCR products were purified using Illustra GFX PCR DNA and Gel Band Purification Kit (GE-Healthcare, United Kingdom) according to the manufacturer's instruction and quantified by BioDrop DUO UV/Vis spectrophotometer (Biochrom, NLD). Sequencing reactions were carried out with ABI 3730 XL Genetic Analyzer (Applied Biosystems, Perkin Elmer, USA), and results were analyzed with CodonCode Aligner software (version 1.6.3; CodonCode Corporation, Dedham, MA). Genetic sequences were compared to the nucleotide database at National Center for Biotechnology Information (NCBI, 2018), and a standard nucleotide-nucleotide BLAST (BLASTn) search was conducted (Altschul et al., 1997).

\section{Phylogenetic analysis}

Phylogenetic analysis was performed with the 50 most similar sequences that were aligned through the BLASTn. The alignment was performed using Clustal X software (Thompson et al., 1997). The results after the alignment were checked, and an evolutionary distance was computed with the p-distance model conducted with the MEGA 6.0 program. Maximum likelihood (ML) phylogenetic trees were constructed using the Molecular Evolutionary Genetics Analysis MEGA 6 (MEGA) software (Tamura et al., 2013). The Kimura two-parameter (K2P) evolutionary sequence model was used in the analysis, with gaps considered as deletions. The reliability of the clade was performed with 1,000 bootstrap replicates per run. Ceratomyxas parusaurati (GenBank accession \#AF411471) was considered as an outgroup to generate phylogenetic trees.

\section{RESULTS}

\section{Histopathology}

In this study, 340 hybrid surubim fish (Pseudoplatystoma reticulatum $\times P$. corruscans), obtained during the co-feeding phase, were analyzed, and $10.93 \%(\mathrm{n}=37)$ had plasmodia of unknown species of Henneguya infecting the gills. The gills showed plasmodia of the Henneguya genus, surrounded by a thick layer of connective tissue, presenting spores at various stages of development (Fig. 1a). Hyperplasia and fusion of secondary lamellae and congestion of some blood vessels constituting branchial arches were observed (Fig. 2a).
Plasmodia whitish, elongated in shape, and measuring up to $3 \mathrm{~mm}$ were in the gill filaments of surubim. The histopathological analyses revealed whitish polysporous cysts, usually ellipsoid and occasionally spherical, mostly infecting the base of the gill. A parasitic infection site by Henneguya sp. in the intra- and inter-lamellar region of the gill filaments was observed (Fig. 2b).

\section{Molecular analysis}

Amplification and sequencing of the 18S rDNA gene of parasites showed fragments of approximately 926 base pairs (bp). The nucleotide sequences were submitted to alignment, and the consensus DNA was deposited in GenBank (accession \#MG820122). BLAST comparison among the sequences showed that the species isolated in this study had a $99.6 \%$ identity with Henneguya pseudoplatystoma (KP981638.1), demonstrating that the evaluated parasite belonged to the species $H$. pseudoplatystoma and was named and deposited at GenBank as H. pseudoplatystoma.

BLASTn aligned the consensus DNA, and the most similar sequences were selected to assess the phylogenetic relationship. This analysis included the 50 most similar sequences and revealed the relationship between parasites of fish from different continents. Maximum likelihood analysis demonstrated that the species evaluated were grouped into six main clades (A-F) and $H$. pseudoplatystoma isolated in MS was strongly grouped by the bootstrap value with another $H$. pseudoplatystoma (GenBank accession \#KP981638) that was isolated in the State of São Paulo, Brazil (Fig. 3). Also, phylogenetic analysis showed that $H$. pseudoplatystoma evaluated in this study were closely related to H. maculosus (Clade E2) besides, in this same clade, we can observe the presence of parasites like the H. eirasi and Aurantiactinomyson sp.

The clade A was divided into three subclades, including the species of parasite Henneguya sp., Myxobolus oliveirai, $M$. filamentum and Aurantiactionomyxon sp. These parasites were isolated from fish families Percidae, Lumbricuidae and Bryconidae. Clade B and C had a single parasite each, M. machidai and Henneguya sp., respectively. They were isolated from fish families Oplegnathidae and Claroteidae, respectively. The clade D was subdivided into two subclades, grouping parasites of species of Henneguya sp., Raabeia sp., Aurantiac-tinomyxon sp. and Helioactinomyxon sp., isolated from fish families Ictaluridae, Heptapteridae and Naididae. The clade E was subdivided into two subclades, grouping parasites like species Myxobolus sp., Auran-tiactinomyxon sp. and $H$. pseudoplatystoma, including the parasite evaluated in this study, as highlightted in the phylo- 

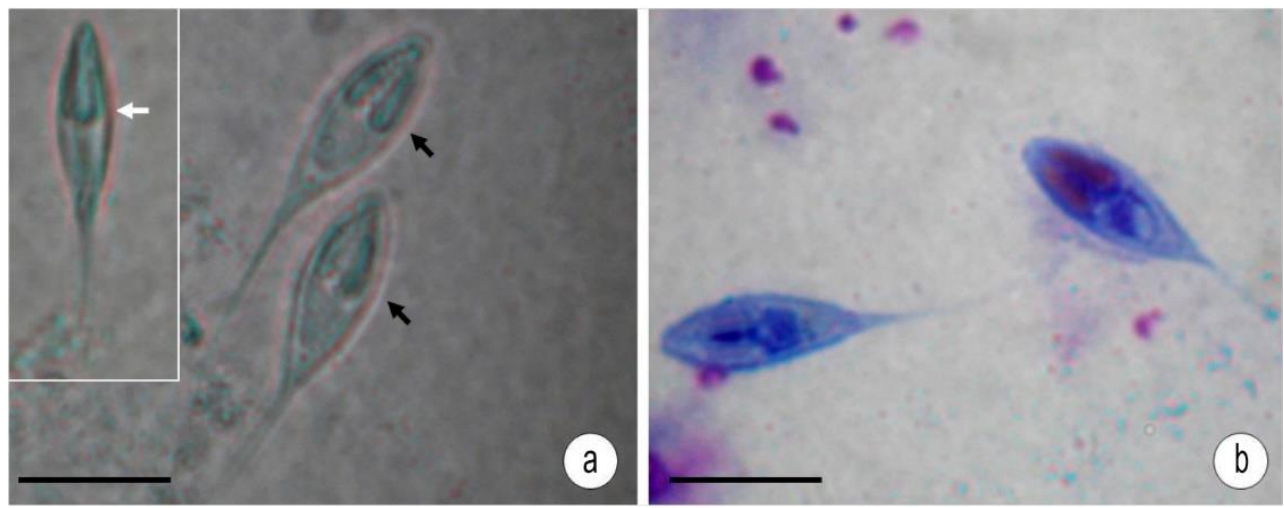

Figure 1. Henneguya sp. parasite of hybrid surubim gills. Henneguya corruscans observed in light microscopy on fresh examination. a) Frontal spore (black arrow) and lateral position (white arrow), b) stained with Giemsa. Bar $=10 \mu \mathrm{m}$.
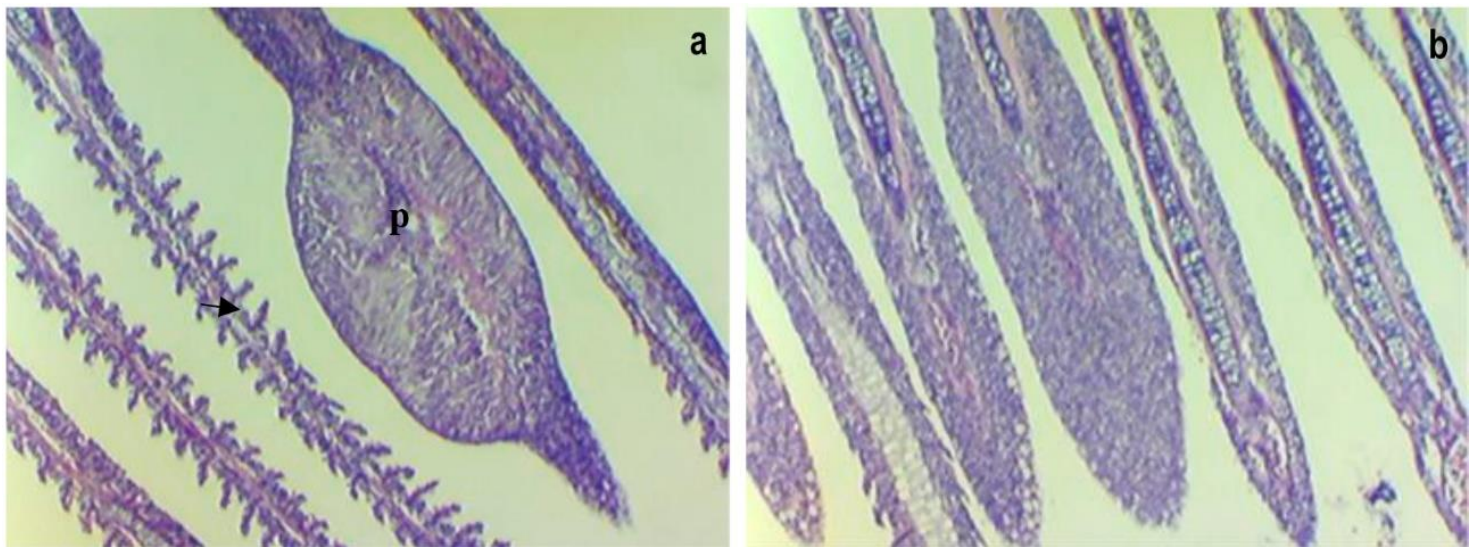

Figure 2. Histological sections of gill filaments of Pseudoplatystoma corruscans infected by plasmodia of Henneguya pseudoplatystoma $\mathrm{n}$. sp. a) showing numerous large plasmodia (p) causing deformation of the filament's structures (black arrows), and b) the presence of diffuse necrosis of the lamellae, and several gill filaments.

genetic tree. These parasites were isolated from fish families Pimelodidae and Naididae. Clade F that was subdivided into two subclades, formed with parasites Sphaeractinomyxon sp., Endocapsa sp. and Myxobolus sp., isolated from fish families Naididae and Mugilidae.

\section{DISCUSSION}

Henneguya pseudoplatystoma has been identified as a parasite infecting farmed fish, such as hybrid surubim, and may lead to a deformation of the gill areas and induce a significant reduction in the epithelial area (Naldoni et al., 2009). Therefore, the negative effect of this condition on fish development needs to be controlled. In this study, we identify a high prevalence of parasites isolated during the initial phase of production from fish farming located in Mato Grosso does Sul, in the central-western region of Brazil.
The species of $H$. pseudoplatystoma parasitizing hybrid surubim was initially identified in the states of São Paulo and Mato Grosso does Sul. When the infection was reported in both states, the rate found was $36.7 \%$. When considering only the samples from Mato Grosso do Sul, $75 \%$ of the fish were infected by $H$. pseudoplatystoma, while in the samples collected in the state of São Paulo, the prevalence was 100\% (Naldoni et al., 2009). In this study, the prevalence of $H$. pseudoplatystoma infection was $10.9 \%$. A similar prevalence $(17.1 \%)$ was found in other species of Henneguya isolated from Pseudoplatystoma in the Brazilian Pantanal (Naldoni et al., 2011). However, a low prevalence of infection rates was related to $H$. multiplasmodialis infection of Pseudoplatystoma corruscans $(3.3 \%)$ and $P$. reticulatum (2.6\%) (Adriano et al., 2012).

The present histopathological examination revealed several morphological alterations in the hybrid surubim 


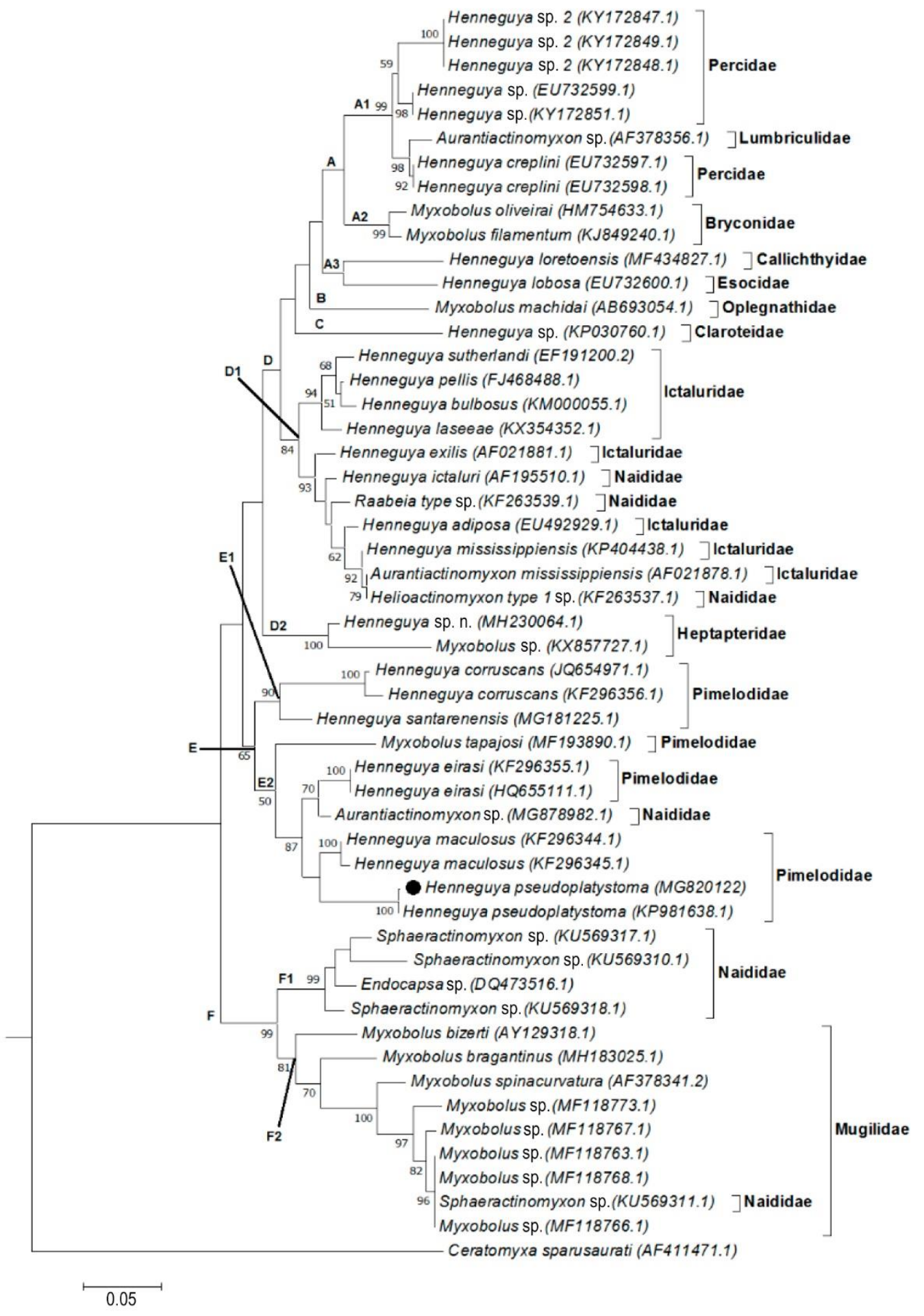

Figure 3. Phylogenetic tree generated through maximum likelihood showing the relationship between Henneguya pseudoplatystoma isolated in Mato Grosso do Sul, Brazil with the 50 most similar sequences aligned with the BLASTn. Dashes are shown for values under 50\%. The H. pseudoplatystoma sequence described in this study is highlighted with a black circle.

fish. H. pseudoplatystoma induced deformations of the filament structures of the lamellae, which may cause a reduction in the area of the functional epithelium, and consequently hamper the development of the host. Also, several gill filaments associated with necrotic foci with large numbers of cysts in the bone tissue were 
observed. The histopathological characteristics of the present species were consistent with those previously described (Naldoni et al., 2009). The gill is a respiratory organ, and alterations in these structures result in different intensities of disease (Naldoni et al., 2009; Adriano et al., 2012). The increasing prevalence and high intensity of infection by this parasite are mainly associated with the poor biological and environmental conditions that are common in fish farms (Naldoni et al., 2009).

Morphological similarities in Henneguya spp. make their identification and differentiation difficult. Molecular biology techniques have enabled the development of taxonomic studies (Adriano et al., 2009). When compared to the Henneguya spp. available at the NCBI, the sequence of $H$. pseudoplatystoma identified in this study, demonstrated $99.6 \%$ identity with $H$. pseudoplatystoma collected from a hybrid surubim ( $P$. corruscans $\mathrm{x} P$. reticulatum) in São Paulo, Brazil (Milanin et al., 2015). Phylogenetic tree constructed, demonstrated that Henneguya species tend to form clades based on the family of the host fish. As reported in prior studies, all parasites of hosts from the same family were clustered together (Ferguson et al., 2008). These results allow us to hypothesize that the ancestors of current hosts were infected by the ancestors of current parasites (Adriano et al., 2012).

The four main clades that were formed by the phylogenetic tree demonstrate that the clade A grouped primarily the parasites that are hosts of the family Percidae in Europe (Molnar et al., 2008), while the clade $\mathrm{D}$ grouped parasites that were hosts of three fish families, Ictaluridae, which has a large number of parasites, followed by Naididae and Heptapteridae (Fig. 3). On the other hand, species grouped in clade, E were identified as parasitizing the Pimelodidae family members in Brazilian territory, including in the southeast and central-western regions (Naldoni et al., 2011; Adriano et al., 2012; Carriero et al., 2013; Milanin et al., 2015), as well as a single parasite that was isolated in the family Naididae. At last, clade F grouped two families of fish Mugilidae and Naididae.

In conclusion, the morphological characteristics associated with molecular data confirmed the identification of the species as $H$. pseudoplastytoma. Molecular techniques, such as $18 \mathrm{~S}$ rDNA gene sequencing is demonstrated to be a faster and sensitive method in identifying fish parasites and may help to develop new management techniques aiming at improving the sanitary indicators, especially during the co-feeding phase, since fishes are more susceptible to pathogens. Additionally, molecular diagnosis appears to be an efficient approach for determining relation- ships between very closely related species, contributing to a better understanding of the evolution of these species and their phylogenetic position.

\section{ACKNOWLEDGMENTS}

The authors thank the National Council of Scientific and Technological Development $(\mathrm{CNPq})$ for the research grant to M.L. Martins (CNPq 305869/2014-0) and (CNPq 484186/2011-6) for the research grant to J.R.C. Mauad. K.E.S. received a scholarship from Coordenação de Aperfeiçoamento de Pessoal de Nível Superior (CAPES), R.O.S., P.M.R. and J.V. from CNPq.

\section{REFERENCES}

Adriano, E.A., Arana, S., Alves, A.L., Silva, M.R.M., Ceccarelli, P.S., Henrique-Silva, F. \& Maia, A.A.M. 2009. Myxobolus cordeiroi n. sp., a parasite of Zungaro jahu (Siluriformes: Pimelodiade) from Brazilian Pantanal: morphology, phylogeny, and histopathology. Veterinary Parasitology, 162: 221229.

Adriano, E.A., Carriero, M.M., Maia, A.A.M., Silva, M.R.M., Naldoni, J., Ceccarelli, P.S. \& Arana, S. 2012. Phylogenetic and host-parasite relationship analysis of Henneguya multiplasmodialis n. sp. infecting Pseudoplatystoma spp. in Brazilian Pantanal wetland. Veterinary Parasitology, 185: 110-120.

Altschul, S.F., Madden, T.L., Schäffer, A.A., Zhang, J., Zhang, Z., Miller, W. \& Lipman, D.J. 1997. Gapped BLAST and PSI-BLAST: a new generation of protein database search programs. Nucleic Acids Research, 25: 3389-3402.

Bush, A.O., Lafferty, K.D., Lotz, J.M. \& Shostak, A.W. 1997. Parasitology meets ecology on its own terms: Margolis et al. revisited. Journal of Parasitology, 83(4): 575-583.

Carriero, M.M., Adriano, E.A., Silva, M.R.M., Ceccarelli, P.S. \& Maia, A.A.M. 2013. Molecular phylogeny of the Myxobolus and Henneguya genera with several new South American species. Plos One, 8: e73713.

Dyková, I. \& Lom, J. 1992. Protozoan parasites of fishes. Developments in Aquaculture Fishery Science, 26: 158-235.

Eiras, J.C., Takemoto, R.M. \& Pavanelli, G.C. 2006. Métodos de estudo e técnicas laboratoriais em parasitologia de peixes. Universidade Estadual de Maringá, Maringá.

Eiras, J.C., Takemoto, R.M. \& Pavanelli, G.C. 2008. Henneguya caudicula $\mathrm{n}$. sp. (Myxozoa, Myxobolidae), 
a parasite of Leporinus lacustris (Osteichthyes, Anostomidae) from the high Paraná River, Brazil, with a revision of Henneguya spp. infecting South American fish. Acta Protozoologica, 47: 149-154.

Ferguson, J.A., Atkinson, S.D., Whipps, C.M. \& Kent, M.L. 2008. Molecular and morphological analysis of Myxobolus spp. of salmonid fishes with the description of a new Myxobolus species. Journal of Parasitology, 94: 1322-1334.

Honorato, C.A., Ushizima, T.T., Santamaria, F.M., Flores-Quintana, C.I., Marcondes, V.M. \& Nascimento, C.A. 2015. Desempenho produtivo e econômica de surubins (Pseudoplatystoma sp.) alimentados com níveis de proteína e estocados em tanque-rede. Arquivo Brasileiro de Medicina Veterinária e Zootecnia, 67: 1408-1414.

Instituto Brasileiro de Geografia e Estatística (IBGE). 2017. Pesquisa de pecuária municipal. Rio de Janeiro. [https://biblioteca.ibge.gov.br/index.php/bibliotecacat alogo?view=detalhes\&id=784]. Reviewed: September 18, 2019.

Jerônimo, G.T., de Pádua, S.B., Ventura, A.S., Gonçalves, E.L.T., Ishikawa, M.M. \& Martins, M.L. 2016. Avaliação parasitológica no híbrido surubim (Pseudoplatystoma reticulatum $\mathrm{x} P$. corruscans), com ocorrência incomum de parasitos Monogenea. Revista Brasileira de Parasitologia Veterinária, 25: 179-186.

Jomori, R.K., Luz, R.K. \& Portella, M.C. 2012. Effect of salinity on larval rearing of pacu, Piaractus mesopotamicus, a freshwater species. Journal of the World Aquaculture Society, 43: 423-432.

Lom, J. 1981. Fish invading dinoflagellates: a synopsis of existing and newly proposed genera. Folia Parasitologica, 28: 3-11.

Lom, J. \& Dyková, I. 2006. Myxozoan genera: definition and notes on taxonomy, life-cycle terminology, and pathogenic species. Folia Parasitologica, 53(1): 1-36.

Manrique, W.G., Figueiredo, M.A.P., de Andrade Belo, M.A., Martins, M.L. \& Molnár, K. 2017. Myxobolus sp. and Henneguya sp. (Cnidaria: Myxobolidae) natural co-infection in the kidney of Piaractus mesopotamicus (Characiformes: Serrasalmidae). Parasitology Research, 116: 2853-2860.

Milanin, T., Maia, A.A.M., Silva, M.R.M., Carriero, M.M. \& Adriano, E.A. 2015. Molecular phylogeny and ultrastructure of Myxobolus cf. cuneus, a parasite of patinga hybrid and Henneguya pseudoplatystoma, a parasite of pintado hybrid. Acta Parasitologica, 60: 442-450.

Received: 29 April 2019; Accepted: 23 September 2019
Molnar, J.L., Gamboa, R.L., Revenga, C. \& Spalding, M.D. 2008. Assessing the global threat of invasive species to marine biodiversity. Frontiers in Ecology and the Environment, 6: 34 pp. doi:10.1890/070064

Naldoni, J., Arana, S., Maia, A.A.M., Ceccarelli, P.S., Tavares, L.E.R., Borges, F.A., Pozo, C.F. \& Adriano, E.A. 2009. Henneguya pseudoplatystoma n. sp. causing reduction in epithelial area of gills in the farmed pintado, a South American catfish: histopathology and ultrastructure. Veterinary Parasitology, 166: 52-59.

Naldoni, J., Arana, S., Maia, A.A.M., Silva, M.R.M., Carriero, M.M., Ceccarelli, P.S., Tavares, L.E.R. \& Adriano, E.A. 2011. Host-parasite-environment relationship, morphology, and molecular analyses of Henneguya eirasi n. sp. parasite of two wild Pseudoplatystoma spp. in Pantanal Wetland, Brazil. Veterinary Parasitology, 177: 247-255.

National Center for Biotechnology Information (NCBI). 2018. Henneguya sp. 2 PBS-2015 18S ribosomal RNA gene, complete sequence. [https://www.ncbi.nlm.nih. gov/nuccore/KP030760.1/]. Reviewed: April 13, 2018.

Peixe BR. 2019. Anuário Peixe BR da Piscicultura 2019. Associação Brasileira de Piscicultura, São Paulo, 148 pp.

Tamura, K., Stecher, G., Peterson, D., Filipski, A. \& Kumar, S. 2013. MEGA6: Molecular evolutionary genetics analysis version 6.0. Molecular Biology and Evolution, 30: 2725-2729.

Tavares-Dias, M. \& Oliveira, M.S.B. 2017. Structure of parasites community in Chaetobranchopsis orbicularis (Cichlidae), a host from the Amazon River system in northern Brazil. Parasitology Research, 116: 23132319.

Thatcher, V.E. 2006. Amazon fish parasites, aquatic biodiversity in Latin America. Pensoft Publishers, Sofia.

Thompson, J.D., Gibson, T.J., Plewniak, F., Jeanmougin, F. \& Higgins, D.G. 1997. The CLUSTAL_X windows interface: flexible strategies for multiple sequence alignment aided by quality analysis tools. Nucleic Acids Research, 25: 4876-4882.

Velasco, M., Videira, M., Sindeaux-Neto, J.L., dos Santos, P., Sanches, O., Matos, P. \& Matos, E. 2015. Infection by Henneguya sp. (Myxozoa) in the bone tissue of the gill filaments of the Amazonian catfish Hypophthalmus marginatus (Siluriformes). Revista Brasileira de Parasitologia Veterinária, 24: 365-369.

Vidal, L.P. \& Luque, J.L. 2017. New morphological data and molecular diagnostic of Henneguya friderici (Myxozoa: Myxobolidae), a parasite of Leporinus friderici (Osteichthyes: Anostomidae) from southeastern Brazil. Revista Brasileira de Parasitologia Veterinária, 26: 81-88. 